\title{
THE REPRESENTATION OF THE SELF-IMAGE OF WOMEN, WHO HAVE EXPERIENCED INCEST
}

Удк 159.9:316.6

DOI https://doi.org/10.32843/2663-

5208.2020.16.21

\section{Душкевич М.М.}

к.психол.н., асистент кафедри

практичної психології

Чернівецький національний університет імені Юрія Федьковича

\section{Глущенко М.о.}

магістрант кафредри практичної психології

Чернівецький національний університет імені Юрія Федьковича
У статті автори торкаються малодослідженої, але вкрай важливої теми - репрезентації Я-образу в жінок, які зазнали інцесту в різні періоди власного життя, здебільшого в дитинстві. Визначено інцест як травматичну подію, що відображається в подальшому на усвідомленні Я-образу жінок. Інцест розглядається не тільки як один із різновидів насилля, а $і$ як тип дисфрункціонального існування сім'ї з порушеними межами та сімейною ієрархією. Розкрито поняття інцестуозності, визначено, як інцестуозні стосунки в сім'ї впливають на фрормування ідентичності особистості. Наведено порівняльний аналіз позитивної Я-концепції та Я-концепції осіб із травмою інцесту. Виокремлено деякі характерні відмінності Я-концепції жінок, які пережили інцест, а саме: нездатність установлювати міжособистісні кордони, повторне зловживання в стосунках, роль жертви, складність говорити «ні», почуття безсилля, викривлене сприйняття образу тіла, труднощі в сексуальній сфрері, проблеми з довірою, безпекою тощо. Здійснено емпіричне дослідження жінок, в анамнезі яких $\epsilon$ інцест. Установлено, що жінки, які зазнали інцесту, суб'єктивно оцінюють власний Я-образ як емоційно-негативний, нейтральний і відчужений схильні репрезентувати Я-образ через соціальні та поведінкові самохарактеристики, описувати себе переважно в термінах власних соціальних ролей, статусів і вчинків. Проаналізовано методом багатомірного шкалювання відповіді жінок на запитання «Хто Я?», визначено специяріку репрезентації їхнього образу Я. Зазначено, що особливістю репрезентації образу Я в жінок, які зазнали інцесту, є утворення специфрічного семантичного простору, де найбільш навантаженими виявилися репрезентації, що засвідчують пережиту травму, а на протилежному полюсі опинилися характеристики, які стосуються жіночої ролі й ідентичності. Наголошено на тому, що травматичний досвід, отриманий у дитинстві внаслідок інцестуозних дій щодо дитини, хроніфрікується й може викликати розлад особистісної ідентифрікації, змінюючи репрезентацію Я-образу вже дорослих жінок.

Ключові слова: Я-образ, жінки, які зазнали інцесту, інцестуозність, травма інцесту, репрезентація Я-образу.
In the article the authors touch upon the issue which is not studied largely, but is extremely important though. This topic is the representation of the self-image of women, who have experienced incest at different periods of their life, mostly in childhood. Incest is defined as a traumatic event, which influences the awareness of the self-image of women. Incest is considered not only as a form of violence, but as a type of dysfunctional existence of a family with broken boundaries and family hierarchy. The concept of incestuousness is revealed. It is defined how incestuous relationships in the family influence the formation of the identity of an individual. A comparative analysis of the positive self-concept and the self-concept of people with incest trauma is presented. Some characteristic differences of the self-concept of women, who have experienced incest, are highlighted, in particular: inability to establish interpersonal boundaries, re-abuse in relationships, the role of the victim, difficulty saying no, feeling of helplessness, distorted body image, sexual difficulties, trust problems, safety problems, etc. An empirical study of women with the anamnesis of incest has been carried out. It is established that women, who have experienced incest, subjectively evaluate their own self-image as emotionally negative, neutral and alienated. They also tend to represent their self-image through social and behavioral self-characteristics and describe themselves mainly in terms of their own social roles, statuses and actions. Women's answers to the question Who am I are analyzed by means of the method of multidimensional scaling and the specifics of the representation of their self-image are determined. It is noted that the peculiarity of the representation of the self-image of women, who have experienced incest, is the formation of a specific semantic space, where the most loaded are the representations that testify to the experienced trauma, and on the opposite side are the characteristics relating to female role and identity. It is emphasized that the traumatic experience gained in childhood, as a result of incestuous actions towards a child, is chronic and can cause a disorder of individual identification, changing the representation of the self-image of already adult women.

Key words: self-image, women, who have experienced incest, incestuousness, incest trauma, representation of self-image.
Постановка проблеми. Згідно з результатам дослідження насильства над жінками в Україні, проведеного під керівництвом ОБСЄ, навесні-влітку у 2018 році, установлено, що більшість жінок в Україні стурбовані проблемою фізичного, психологічного та сексуального насильства над жінками, зокрема 64\% із них кажуть, що це поширене явище. Отже, майже половина жінок, починаючи з того часу як їм виповнилося 15 років, зазнали сексуального домагання, а 1/4 частина говорить про досвід пережитого насильства в дитинстві (до 15 років). Досліджувані визначають, що батьки (батько або матір) були основними винуватцями, а випадки насильства ставалися більше ніж один раз. На жаль, домінує в описа- 
ній статистиці сексуальна експлуатація жінок, інцест зокрема [5].

Аналіз останніх досліджень і публікацій. Проблематика інцесту в психологічній теорії та практиці залишається однією з найскладніших. Різні автори здійснювали підходи до розуміння та пояснення явища інцесту з погляду системно-сімейного підходу (Н. Оліфірович, І. Малкіна-Пих, В. Меновщиков, Е. Ейдеміллер); психодинамічного, серед яких і класики, і сучасники (3. Фройд, Н. Мак-Вільямс, П. Куттер, П. Раком'€, Е.В. Уеллдон, У. Віртц, С. Шерков, С. Аврамченко, Л. Старович, Ф. Капріо, Д. Глуговський, Г. Дерягін); психотерапевтичного (Ю. Бєлькіна, Г. Малейчук, А. Антонова, Т. Леонідова, В. Виноградова) підходів.

Торкаючись проблематики інцестуозних стосунків, Н. Оліфірович і З. Старович диференціюють поняття психологічного та фізичного інцесту. Фізичним інцестом науковці називають інтимний і статевий зв'язок між членами однієї сім'ї, наприклад, між батьками і дітьми, між сиблінгами або кровними родичами тощо. Психологічний сенс інцесту передбачає дії із сексуальним підтекстом, що відбуваються стосовно об'єкта інцесту для задоволення сексуальних потреб агресора, який емоційно пов'язаний із незалежною від нього людиною і $€$ авторитетом для неї. Інцест не завжди включає сексуальний контакт або дотик, він може мати тільки психологічне підґрунтя, значення якого полягає в переживанні жертвою почуття здійсненого над нею насильства (наприклад, відверті розмови про секс, перегляд еротичних фільмів у присутності дитини; ситуації, коли дитина чує крики зі спальні батьків чи коли вона бачить сам статевий акт) [7; 10].

Французький психіатр і психоаналітик П. Ракам'є вводить ще один термін - «інцестуозність», явище якого полягає в поєднанні фізичного та психологічного компоненту інцесту, де власне коїтусу немає, але побічно фізичні дії важливих дорослих мають переважно психологічний, сексуальний підтекст [8; 13].

Психологи-практики В. Виноградова й І. Соловйова відмічають, що жертвою інцесту $€$ дитина або дорослий, стосовно яких скоєно фізичне насильство із сексуальним підтекстом або безпосередньо статевий акт; психологічне насильство, що включає моральний тиск із сексуальним підтекстом; залучення до розмов і жартів на сексуальні теми; демонстрацію сексуальних дій у присутності об'єкта інцесту [2; 9].

Доведено, що, незалежно від того який вид інцесту здійснено над дитиною, наслідки $€$ однаково складними й часто спричинюють порушення емоційного, фізичного чи психічного спектру [12].

Постановка завдання. Мета статті дослідити малодосліджену, але вкрай важливу тему - репрезентацію Я-образу в жінок, які зазнали інцесту в різні періоди власного життя, здебільшого в дитинстві.

Виклад основного матеріалу дослідження. Здійснюючи аналіз наукових розвідок учених, ми простежили, що науковці розглядають інцест у розрізі психічної травми, що являє собою свого роду «напад» на особистісну організацію, такий, який унеможливлює людинуасимілювати життєвий досвід звичним способом. Порушується психічна рівновага, де психічні інстанції не функціонують нормативним чином. Психоаналіз визначає травму як загрозу когерентності внутрішніх селф-об'єктних стосунків і загрозу когерентній самості [12-14].

Австрійський психоаналітик У. Віртц роз'яснює, що переживання інцесту екзистенційно $€$ більш загрозливим, ніж простий стрес. Авторка уточнює, що сексуальна експлуатація може об'єктивно бути важким, критичним життєвим досвідом, який має місце не один раз, а протягом кількох років життя. У дитинстві, коли життєві цінності ще тільки формуються, сексуальне насильство завдає цим цінностям величезної шкоди. Природний розвиток емоційної сфери, мислення й поведінки сильно порушується, що може призвести до фіксації, повністю перешкоджає подальшому формуванню особистості. Сексуальна експлуатація робить людину безпорадною та безсилою, знищує впевненість у своїй здатності контролювати ситуацію; через це глибоко порушується здатність діяти [3].

Знаходимо актуальною модель Фінкельхора, яка відображає специфіку особистості, характерну для жертв інцесту: 1) травматична сексуалізація; 2) стигматизація; 3) відчуття зради; 4) переживання безсилля [14].

Досліджуючи проблему інцесту, ми порівняли структуру позитивної Я-концепції особистості з Я-концепцією людини, яка пережила сексуальну експлуатацію та має в анамнезі травму інцесту (див. таблицю 1).

Опираючись на теорію П. Ракам'є, який описує інцестуозність на прикладі сімей зі змішаною ієрархією, ми погоджуємося з ідеєю, що інцестуозність - це пов'язані з інцестом усвідомлені чи неусвідомлені потяги, або бажання, або фантазії, які інцестні за своєю природою. Інцестуозність може демонструвати атмосферу інцесту з наявним сексуалізованим психологічним підґрунтям, коли в сім'ї є загроза фізичного інцесту, але безпосередньо статевий акт відсутній.

Феномен інцестуозності, відповідно, пов'язаний із такими проблемами, як формування ідентичності особистості, становлення особистісних границь, порушення Я-концепції тощо [13].

На думку російського психотерапевта Н. Оліфірович, люди, які пережили в дитин- 
Особливості позитивної Я-концепції та Я-концепції особистості, яка зазнала інцесту

\section{Структура позитивної я-концепції \\ Структура Я-концепції особистості, яка зазнала інцесту}

1. ФізичнийЯ-образ, що викликає потребу 1 . Пригнічений настрій, «безпричинний» плач.

фізичного благополуччя організму.

2. Фантазії про самогубство, суїцидальні спроби.

2. Соціальна ідентичність: статева, вікова, 3. Саморуйнівні дії, самоушкодження, заподіяння собі етнічна, громадянська, соціально-рольова, болю, часті нещасні випадки.

яка пов'язана з потребами людини належ- 4. Адиктивна поведінка.

ності до соціуму (К. Хорні).

3. Диференційований образЯ, щохарактеризує знання про себе порівняно з іншими людьми й тим, що надає відчуття власної унікальності, забезпечує потребу в самовизначенні та самореалізації (В. Столін).

4. Власні, парціальні самооцінки;

5. Відносно цілісна Я-концепція;

6. Я-концепція як частина системи ціннісних орієнтацій особистості (І. Кон та ін.).

7. Здатність відкрито говорити про свої бажання та потреби, почуття.

8. Здатність сказати «ні».

9. Уміння встановлювати, підтримувати й закінчувати розмову. Здатність до рефлексії (А. Лазарус).

10. Ставлення до інших людей, демонструючи уважливість, принциповість, прихильність, комунікативність, миролюбність, лагідність, альтруїзм, дбайливість, тактовність, коректність або протилежні риси.

11. Ставлення до справ, виявляючи сумлінність, допитливість, ініціативність, рішучість, ретельність, точність, серйозність, ентузіазм, зацікавленість або протилежні риси; до речей, демонструючи при цьому бережливість, економність, акуратність, почуття смаку або протилежні риси.

12. Ставлення до себе, виявляючи розумний егоїзм, упевненість у собі, нормальне самолюбство, почуття власної гідності чи протилежні риси.

5. Почуття провини й сорому, низька самооцінка.

6. Недовірливість, страх самовіддачі й утрати контролю або нездатність оцінити надійність іншої людини.

7. Нездатність установлювати міжособистісні кордони, повторне зловживання в стосунках, звична роль жертви, утруднення сказати «ні», почуття безсилля.

8. Надмірно конфліктні стосунки, проблеми з амбівалентністю, уникнення близькості й вибір партнера, який не допускає близькості із собою.

9. Відчуття ізольованості, відчуження та деперсоналізація, відщеплення емоцій, рефлекс «уявної смерті»: фізична і психічна паралізованість у певних ситуаціях або під час розмови на певну тему.

11. Стигматизація. Почуття власної табуйованості, тому що порушено табу. Страждання від почуття належності, носія страшної таємниці.

12. Флешбеки: раптові візуальні спогади про травму, які відчуваються як напад.

13. Відчуття «застрягання» й задухи, «комка» в горлі, утруднене ковтання, дихання, шкірні висипання, свербіж. 15. Помітні прогалини в пам'яті, нездатність згадати всі періоди дитинства, розмиті образи певних людей і ситуацій. Недоречні сильні емоційні реакції під час перебування у відомих місцях або зустрічей із деякими людьми.

17. Проблеми в сексуальній сфері: уникання всього сексуального; не розрізняються сексуальність, влада, контроль і насильство; невизначена гендерна ідентичність; порушення оргазму; неможливість поєднати секс і ніжність, відраза до всього тілесного (у тому числі запахи і звуки).

18. Спотворений образ тіла: тіло сприймається зрадженим, ховається під мішкуватим одягом, щоб бути непомітним (С. Блум).

стві психологічний чи фізичний інцест, стаючи дорослими, згодом відчувають труднощі в створенні глибоких, заснованих на взаємності стосунків, легко вступають у поверхові контакти, не отримуючи задоволення, легко їх переривають, що сприяє розвитку адикцій, сексуальних дисфункцій, компульсивностей. Авторка стверджує, що це пов'язано з хронічним страхом особистості бути покинутою людьми, які співпереживають їй і піклуються про неї. Для жертв інцесту характерний постійний пошук «досконалого» партнера, бажання встановлення унікальних стосунків, заснованих на взаємній любові [7; 11].

Емпіричне дослідження Я-концепції особистості, яка пережила інцест, і репрезентацій Я-образу жінок, які зазнали інцесту, проводилося з лютого до березня 2019 року. Для реалізації дослідження нами сформовано вибірку, що складалася з двох груп: перша група, екс- периментальна (ЕГ) - жінки, у житті яких зафіксована травма інцесту (16 досліджуваних), друга група - контрольна (КГ), випадкового складу та сукупності (40 досліджуваних). Вік досліджуваних - від 21 року й вище. Процедура передбачала заповнення бланків звичайного зразка та електронних, створених за допомогою платформи Google Forms. В емпіричному дослідженні як експериментальна група взяли участь клієнти з травмою інцесту, які проходять особисту терапію в психотерапевта, що спеціалізується на цій проблемі. Дослідження відбулося з дотриманням принципу конфіденційності й усіх вимог до проведення такого роду досліджень.

Для реалізації мети та завдань емпіричного дослідження нами використовувалися психодіагностичні методики: «Ранні дезадаптивні схеми» (Дж. Янг), «Шкала оцінювання впливу травмуючої події» (М. Горовіц, Н. Віль- 
нер), «Психологічна суверенність особистості» (С. Нартова-Бочавер), «Індекс життєвого стилю» (Р. Плутчик, Г. Келлерман і Х. Конт); «Хто Я?» (М. Кун, Т. Макпартленд), «Шкала психологічного інцесту» (авторська). Для обробки емпіричних даних використовувалися якісний, кількісний і контент-аналіз, а також статистичний аналіз за допомогою пакету статистичних програм SPSS, 21.

3 висновками щодо специфіки Я-концепції жінок, які зазнали інцесту, можна ознайомитися в статті «Особливості я-концепції особистості, яка пережила інцест» М. Душкевич, М. Глущенко, 2019 [4].

Задля дослідження основних компонентів Я-образу особистості та їх суб'єктивної оцінки нами використана методика «Хто Я?» М. Куна, Т. Макпартленда [6].

Як засвідчують дані (рис. 1), середній показник об'єктивного компоненту Я-образу в експериментальній групі вищий, ніж у контрольній групі. Відповідно, ми спостерігаємо, що суб'єктивний компонент Я-образу вищий у контрольній групі.

Спираючись на отримані результати, ми бачимо, що жінки з експериментальної групи більш схильні оцінювати власний Я-образ як емоційно негативний, аніж досліджувані з контрольної групи. Емоційно позитивне ставлення до себе переважає в жінок із контрольної групи. Жінки з травмою інцесту демонструють дещо більші показники нейтрального та відчуженого ставлення до власної ідентичності.

Дослідження встановило, що особи, у житті яких $є$ травма інцесту, схильні розглядати Я-образ в об'єктивному аспекті, що включає соціальні та поведінкові самохарактеристики, описують себе переважно в термінах власних соціальних ролей, статусів і вчинків; мають переважно емоційно-негативну оцінку власної особистості.

На наступному етапі емпіричного дослідження отримані висловлювання в групі жінок з інцестом ми розглядали як частину семантичного простору. Ми опиралися на думку О. Артем'євої про єдину психічну реальність, переживання якої створює семантичне визначення якості об'єктів, де висловлювання про себе $є$ метафоричним вираженням станів і відносин об'єкта [1].

Аналогом семантичної відстані між поняттями була частота зустрічей однакових репрезентацій Я-образу в різних досліджуваних. Дані подавалися мовою оригіналу.

На етапі статистичної обробки застосований метод багатомірного шкалювання з використанням моделі відстані Евкліда (рис. 2).

Ураховуючи характер розосередження, можна інтерпретувати цю діаграму так. Очевидно, високої концентрації сягають репрезентації «тінь», «привид себе самої», «гарний актор», «досить похмура особистість», «утома й сон», які здебільшого забарвлені песимістично та відчужено й можуть інтерпретуватися як відображення травми інцесту.

Наступними репрезентовані такі характеристики Я-образу: «тітка», «любима», «українка», «Я - мама», «особистість», «друг», «дослідник», що є відображенням соціальних ролей досліджуваних жінок.

Далі зі зсувом до негативного полюсу репрезентовані такі характеристики жінок:

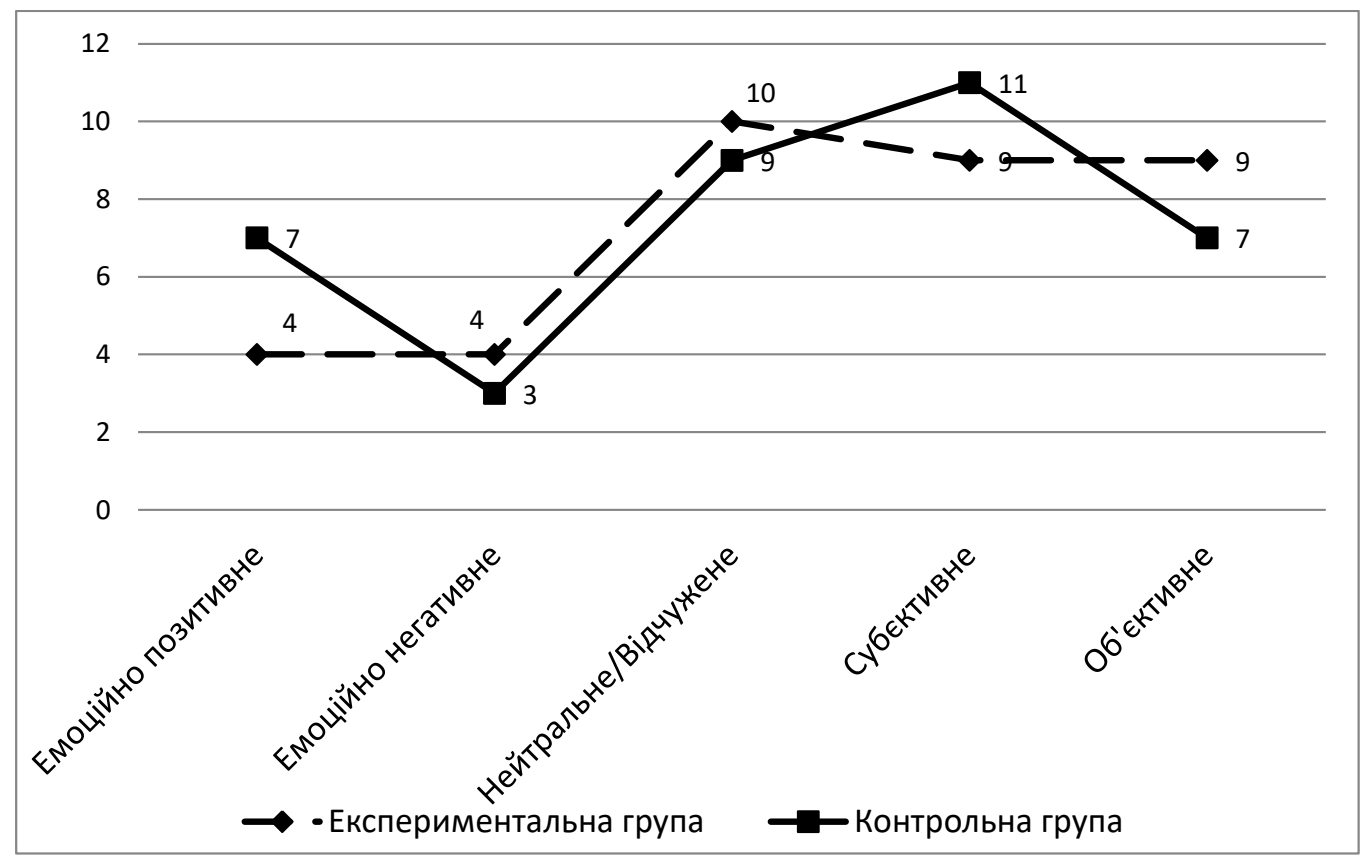

Рис. 1. Середні показники суб'єктивної оцінки й ставлення до компонентів я-образу в осіб експериментальної та контрольної груп 


\section{Выведенная конфигурация стимулов}

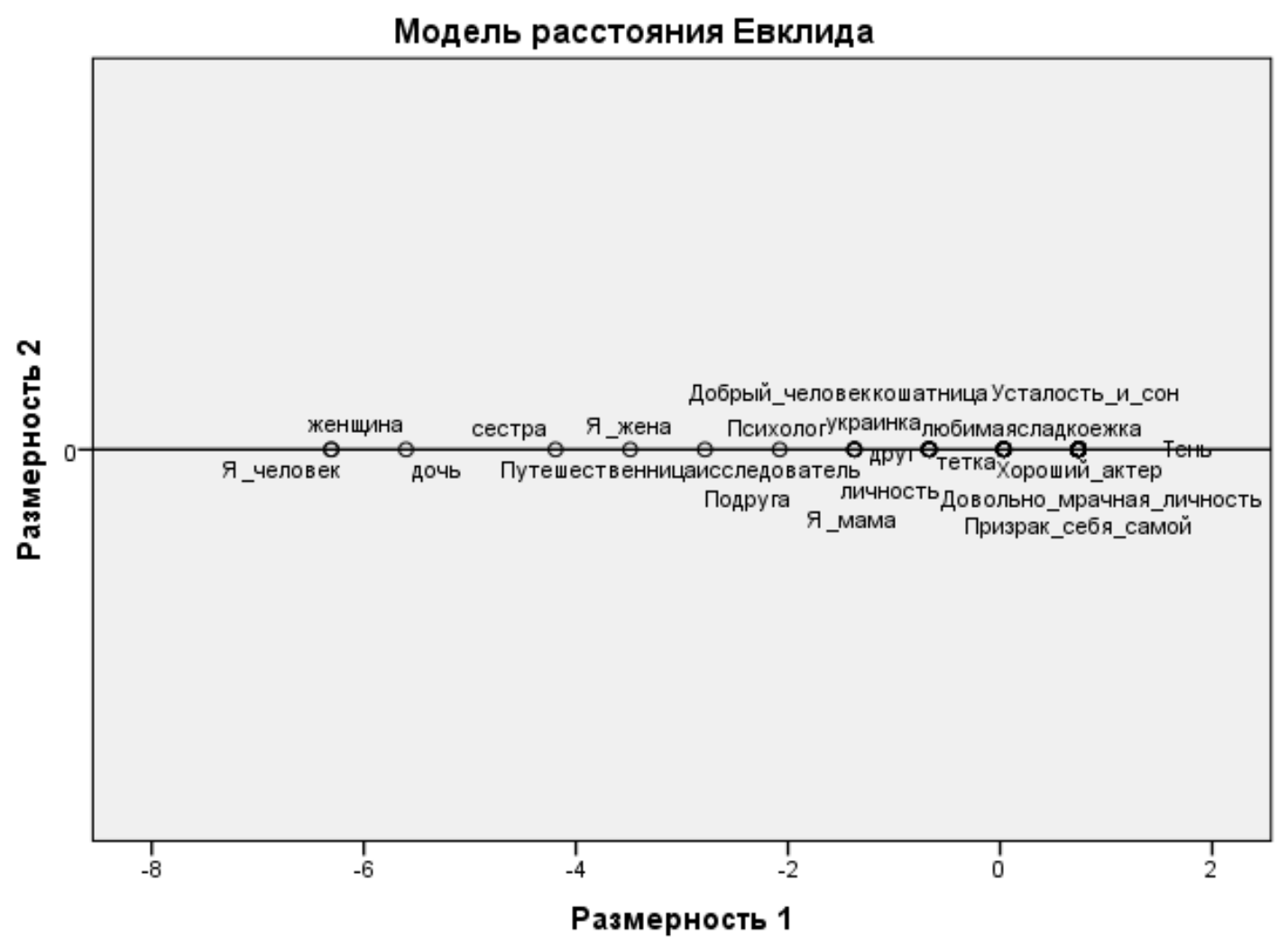

Рис. 2. Діаграма репрезентацій Я-образу жінок за результатами багатомірного шкалювання

«подруга», «мандрівниця», «Я-дружина», «добра людина», «психолог», «сестра».

Негативно навантаженими виявилися характеристики, що мали високу частоту представлення: «донька», «жінка», «Я - людина», які пов'язані із жіночою ідентичністю.

Дослідження виявило характерну полярність у характеристиках образу Я жінок, які зазнали інцесту: частина з них ілюструє соціальні ролі: «Я - людина», «жінка», «донька», «подруга», «мандрівниця», інша частина вказує на пережиту травму: «Я - пуста кімната, пустота», «сексуальний об'єкт в очах чоловіків», «привид себе самої», «жертва», «суцільні втрати», «Я - надламана», «нескінченний біль» тощо.

Отже, особливістю репрезентації образу Я в жінок, які зазнали інцесту, є утворення специфічного семантичного простору, де найбільш навантаженими виявилися репрезентації, що засвідчують пережиту травму, а на протилежному полюсі опинилися характеристики, які стосуються жіночої ролі та ідентичності.

Можемо припустити, що отримані дані є взаємопов'язані, оскільки, згідно з теоретичними дослідженнями, жіноча ідентичність зазнає найбільшого ураження внаслідок пережитого жінкою інцесту.

Висновки 3 проведеного дослідження. Отже, структура Я-концепції особистості, яка пережила інцест, відрізняється від позитивної структури особистості. Люди, які пережили інцест, відчувають труднощі в створенні глибоких, заснованих на взаємності стосунків, легко вступають у поверхові контакти, не отримуючи задоволення, легко їх переривають, що сприяє розвитку адикцій, сексуальних дисфункцій, компульсивних дій. Досвід насилля, отриманий у дитинстві, зажди є травматичним і часто призводить до розладів особистісної ідентифікації та порушень у сприйнятті Я-образу жінками. Так, зокрема, сексуальна експлуатація через інцест призводить до порушення сприйняття власного тіла, зміни ставлення до себе та близьких.

Основними переживаннями, які відчувають жертви інцесту, є страх, сором, провина, через призму яких формується уявлення про себе. Репрезентації Я-образу жінок, які зазнали інцесту, мають здебільшого песимістичний негативний, подекуди функціональний характер, що відображає пережитий травматичний досвід. 


\section{ЛІТЕРАТУРА:}

1. Артемьева Е.Ю. Основы психологии субъективной. Москва : Смысл, 1999. 350 с.

2. Виноградова В. Психологический инцест. «Счастье» материнства. URL: https://gestaltclub.com/ articles/obsaa-psihologia/7106-psihologiceskij-incestscaste-materinstva.

3. Виртц У. Убийство души: инцест и терапия. Москва : Когито-Центр, 2014. 293 с.

4. Душкевич М.М., Глущенко М.О. Особливості Я-концепції особистості, яка пережила інцест. Молодий вчений. 2019. № 7 (1).С. 24-27. URL: http://molodyvcheny.in.ua/files/journal/2019/7/6.pdf.

5. Добробут i безпека жінок. Дослідження насильства над жінками в Україні. Проведено під керівництвом ОБСє. 2019. 114 с.

6. Методики вивчення повсякденного стресу і способів розв'язання кризових життєвих ситуацій / О.Я. Кляпець, Б.П. Лазоренко, Л.А. Лєпіхова, В.В. Савінов ; за ред. Т.М. Титаренко. Київ : Міленіум, 2009. $120 \mathrm{c}$.
7. Олифирович Н.И., Зинкевич-Куземкина Т.А., Велента Т.Ф. Психология семейных кризисов. Санкт-Петербург : Речь, 2006. 360 с.

8. Потапова В.А. «Инцестуозность» в современной психоаналитической теории и практике. Российский психиатрический журнал. 2003. № 2. С. 16-21.

9. Соловьева И. Секс - не игрушка! О сексуальном абьюзе. URL: https://cutt.ly/1fwan4H.

10. Старович 3.Л. Судебная сексология / пер. с польск. Д.К. Лунин, В.П. Ольховик. Москва : Юридическая литература, 1991. 332 с.

11. Стреленко А.А. Я-образ в сознании подростков, переживших сексуальное насилие : учебно-методическое пособие. Витебск, 2003. 42 с.

12. Уэлдон Э.В. Мать. Мадонна. Блудница. Идеализация и обесценивание материнства. Москва : Перо, 2016. 204 c.

13. Racamier P-C. L'inceste et l'incestuel. Les Edition du College, 1995.

14. Finkelhor D. Child Sexual Abuse. New York, 1984. P. $186 f$ 